\title{
Susceptibility of two strains of rainbow trout (one with suspected resistance to whirling disease) to Myxobolus cerebralis infection
}

\author{
Ronald P. Hedrick ${ }^{1, *}$, Terry S. McDowell ${ }^{1}$, Gary D. Marty ${ }^{2}$, Geoffrey T. Fosgate ${ }^{1}$, \\ Kaveramma Mukkatira ${ }^{1}$, Karin Myklebust $^{1}$, Mansour El-Matbouli ${ }^{3}$ \\ ${ }^{1}$ Department of Medicine and Epidemiology, and 2Department of Anatomy, Physiology and Cell Biology, School of \\ Veterinary Medicine, University of California, One Shields Avenue, Davis, California 95616, USA \\ ${ }^{3}$ Institute of Zoology, Fishery Biology and Fish Diseases, Faculty of Veterinary Medicine of the Ludwig Maximilians, \\ University of Munich, Kaulbachstrasse 37, 80539 Munich, Germany
}

\begin{abstract}
The susceptibility of 2 strains of rainbow trout Oncorhynchus mykiss, 1 from North America (TL) and 1 from Germany (GR), to Myxobolus cerebralis (the cause of salmonid whirling disease) was assessed following exposure to the infectious stages (triactinomyxons). Two laboratory experiments were conducted with age-matched rainbow trout of each strain. At the beginning of the study, the 2 trout strains were aged ca. 570 degree-days in Expt 1, and ca. 999 degree-days in Expt 2. In both experiments, replicate groups of each trout strain were exposed to 10, 100, 1000 or 10000 triactinomyxons (TAMs) fish ${ }^{-1}$ for $2 \mathrm{~h}$. The fish were then held in aquaria receiving $15^{\circ} \mathrm{C}$ well-water. Severity of infection was evaluated 5 mo after exposure by presence of clinical signs (whirling and/or black tail), prevalence of infection, severity of microscopic lesions, and spore counts. Clinical signs of whirling disease were evident only in the younger fish exposed in Expt 1: These occurred first among TL rainbow trout at the highest dose at 6 to $7 \mathrm{wk}$ post exposure and then $2 \mathrm{wk}$ later in fish at the 1000 TAMs dose. Black tail was also observed among GR rainbow trout at the 10000 TAMs dose only, but in fewer fish. The prevalence of infection, spore numbers, and severity of microscopic lesions due to M. cerebralis among GR rainbow trout were less at all doses compared to TL rainbow trout. Risk of infection analyses showed that TL rainbow trout were more prone to infection at the lower doses than GR trout. Mean spore counts were consistently (10- to 100-fold) less in GR than TL trout at doses of 1000 TAMs or lower. Microscopic lesions increased with increasing dose in both strains of rainbow trout. The mechanisms underlying the greater resistance of the GR strain to $M$. cerebralis infections are unknown, but are under investigation as part of a long-term project to determine the basis for resistance and susceptibility of salmonid fishes to whirling disease.
\end{abstract}

KEY WORDS: Myxobolus cerebralis $\cdot$ Rainbow trout $\cdot$ Disease resistance $\cdot$ Whirling disease

\section{INTRODUCTION}

Whirling disease and the associated myxosporean agent Myxobolus cerebralis were first described in Europe in 1898 among farmed rainbow trout (Hofer 1903). Through intercontinental movements of fishes, the agent was presumably spread from an origin in Eurasia throughout Europe and eventually to the USA (Hoffman 1970, 1990). The potential impacts of the parasite on wild populations of trout initially reported by Yoder (1972) became evident when, in 1990, fishery biologists detected significant declines in populations of wild rainbow trout in North America (Nehring \& Walker 1996, Vincent 1996). The severe declines in these wild rainbow trout populations stimulated a renewed interest in exploring the causes of whirling disease. Building upon the initial discovery by Wolf \& Markiw (1984) of the 2-host life cycle of the parasite, recent research has greatly increased our knowledge of both the fish and oligochaete hosts (Hedrick 1998, 
Hedrick et al. 1998, Bartholomew \& Wilson 2002). Part of the more recent research on whirling disease has been the search for naturally acquired resistance to the parasite among strains of rainbow trout in North America, but both field and laboratory studies have demonstrated no more than marginal resistance to the parasite among the many stocks of rainbow trout in North America (Hedrick et al. 1998, 1999a,b, 2001, Thompson et al. 1999, Densmore et al. 2001).

Observational and experimental studies show that rainbow trout are one of the most susceptible species of salmonid to Myxobolus cerebralis (Hofer 1903, Schäperclaus 1931, Hoffman \& Putz 1969, Halliday 1976, O'Grodnick 1979, Hoffman 1990, Markiw 1992a, MacConnell \& Vincent 2002). This is presumed to be in part due to the independent evolution of the parasite and rainbow trout. Only when rainbow trout were introduced to Europe from North America in the late 19th century did the host and parasite first come into contact (Hofer 1903). The initial observations of Hofer (1903) record the results of these first encounters that were characterized by radical tail-chasing swimming (whirling), darkened caudal region (black tail), skeletal deformities and death among young rainbow trout raised in trout farms in Germany. This reaction between the host and parasite was quite different from the few or no signs observed in the native salmonid brown trout Salmo trutta reared at the same farms.

Field and laboratory studies have demonstrated a range in susceptibility to whirling disease among salmonid fishes (Hoffman \& Putz 1969, Halliday 1976, O'Grodnick 1979, El-Matbouli et al. 1992, Hedrick et al. 1998, 1999a,b, Thompson et al. 1999, Densmore et al. 2001). Early phases of the infection, including attachment and initial penetration of the epidermis, occurs in all species of salmonids examined (El-Matbouli et al. 1999). It is the subsequent development that influences the ultimate fate of the parasite: this differs greatly among salmonid species (Hedrick et al. 1998). Differences in the host responses to the parasite offer a unique opportunity for examining the role of host factors in the resistance and susceptibility of salmonid fishes to whirling disease. The fact that resistance and susceptibility to disease are not direct opposites, and that each may possess separate genetic mechanisms (Hawken et al. 1998) makes the study of the host responses of salmonids to Myxobolus cerebralis even more intriguing. In this study, we examined a population of rainbow trout in Germany that has had presumed contact with the parasite for up to $110 \mathrm{yr}$ and that has shown empirical resistance to whirling disease in the field. We compared the relative susceptibility of this German strain and a representative strain of rainbow trout from North America to controlled laboratory exposure to $M$. cerebralis.

\section{MATERIALS AND METHODS}

Fish. The TL rainbow trout were obtained as eyed eggs from a commercial hatchery (Trout Lodge, Sumner, Washington, USA). The GR rainbow trout were obtained as yolk sac fry from a private hatchery in Bavaria, Germany. Fry from the TL eggs and fry from Germany were reared in well-water at temperatures from 10 to $13^{\circ} \mathrm{C}$ until they were a similar age in degreedays. Fish were fed a commercial trout diet and held in 201 aquaria receiving $15^{\circ} \mathrm{C}$ well-water prior to experimentation. Two separate experiments were conducted with the same initial groups of fish of each strain of rainbow trout. In Expt 1, the rainbow trout from TL were 569 degree-days and the GR strain were 572 degreedays at the time of exposure to Myxobolus cerebralis. In Expt 2, the TL fish were an average age of 998 degreedays and the GR 1000 degree-days.

Experimental exposure of trout. Experimental exposure of both rainbow trout strains to Myxobolus cerebralis was identical to that described in our prior comparison of the susceptibility of rainbow trout and brown trout (Hedrick et al. 1999a), and comprised exposure of 2 replicate groups of fish of each strain in containers with $500 \mathrm{ml}$ of $15^{\circ} \mathrm{C}$ well-water at each of 4 exposure doses $\left(10,100,1000,10000\right.$ TAMs fish $\left.^{-1}\right)$. A total of 13 fish were added to each container; 2 additional containers for each strain of trout contained no triactinomyxons $\left(0 \mathrm{TAMs}^{\mathrm{fish}}{ }^{-1}\right)$. After $2 \mathrm{~h}$, the fish were removed from each container and placed into individual $20 \mathrm{l}$ aquaria receiving single-pass $(0.5 \mathrm{l}$ $\left.\min ^{-1}\right) 15^{\circ} \mathrm{C}$ well-water for the duration of the experiment. The fish were fed once or twice daily with a commercial trout ration.

Assessments of infection. Clinical signs, histopathology and spore concentrations were determined as follows.

Clinical signs and prevalence of infection: The onset of clinical signs, including a tail-chasing swimming behavior (whirling), and darkening of the caudal peduncle region (black tail) were recorded daily as described by Hedrick et al. (1999a). The prevalence of infection at 5 mo post exposure was calculated by removing 10 fish from each replicate group. Each fish was examined for the presence of black tail, euthanized with $500 \mathrm{\mu g} \mathrm{ml}^{-1}$ benzocaine, and then one-half of the head was preserved in Davidson's solution for histopathological analyses while the other half was used for determining spore concentrations.

Histopathology scoring: A total of 10 fish from each replicate group collected at 5 mo post exposure from Expt 1 were prepared for histopathological evaluation and scored for severity of microscopic lesions. Because clinical signs of whirling disease were not evident in Expt 2, tissues were not subjected to scoring. For each 
fish, a single mid-saggital section of the head was scored for severity of microscopic lesions as described by Hedrick et al. (1999a) and modified from that of Baldwin et al. (2000). Lesions were scored on a scale ranging from 4 (most severe) to 0 (no lesions).

Spore concentrations: The detection and enumeration of spores after pepsin-trypsin digestion (Markiw \& Wolf 1974a) of the half-heads of 10 fish from each replicate group were identical to those described by Hedrick et al. (1999a). A fish was scored as infected if any spores were observed. The prevalence of infection (number of fish in which spores were detected divided by the total number of fish examined) was then determined at each dose of exposure. In addition, mean spore concentrations were calculated for the replicate groups at each exposure dose. In this study, fish in which no spores were detected were included in the calculations of the mean spore concentrations for comparison. Analytic methods evaluating effects of dose, species, and age of fish (Expt 1 vs Expt 2) on mean spore concentrations were performed using conservative estimates that included zero values in calculations, as well as methods previously conducted by Hedrick et al. (1999a) which calculated means conditional on fish infection-status.

Statistical analyses. To evaluate differences in susceptibility between strains at various doses, a ratio of the prevalence of infection in TL rainbow trout over the respective prevalence in GR rainbow trout for each dose of exposure was constructed. Because all fish in the sample were free from infection at the beginning of the experiment and were all exposed to a selected dose, the prevalence of infection at each dose represented the risk of infection at 5 mo post exposure. These calculated prevalence ratios are referred to subsequently as risk ratios (RR). Risk ratios and the respective $95 \%$ confidence intervals (CI) were calculated using a statistical software package (SPSS $^{\circledR}$ Version 10.0 for Windows, Chicago, Illinois USA). For comparison of all treatments, a $5 \%$ level was used to determine significance. Comparisons of spore numbers were conditional on the fish having undergone exposure to triactinomyxon stages; therefore, the unexposed control group was excluded. A general linear model approach was used to assess the effects of species, dose, and age of first exposure (Expt 1 vs Expt 2) on the number of spores present at 5 mo post exposure. To satisfy statistical assumptions of the procedure, spore numbers were $\log _{10}$-transformed to make their distribution more normal. Interaction effects between strains, dose, and age were investigated using a linear model. Subsequently, main effects of strain, dose, and age were assessed separately using Mann-Whitney non-parametric tests. Mann-Whitney tests were also used to compare the median number of spores in TL to those in
GR rainbow trout at each dose level. Additionally, polynomial contrasts in the general linear model analysis were used to evaluate the trend in log number of spores recovered for each fish strain over increasing infection doses.

\section{RESULTS}

\section{Clinical signs and prevalence of infection}

There were no indications of whirling disease among control rainbow trout (non-exposed) of either strain in Expts 1 or 2 . In Expt 1 with the younger fish, black tail occurred among TL rainbow trout at the 2 highest doses of exposure to Myxobolus cerebralis (1000 and 10000 TAMs fish ${ }^{-1}$ ) and only at the highest dose in the GR strain (Table 1). Differences between the 2 trout strains were most remarkable at the 1000 TAMs dose, where $30 \%$ of the TL fish compared to no GR fish showed clinical signs. At the highest dose of parasite exposure, all TL fish showed clinical signs compared to only $56 \%$ of the GR fish. None of the fish in Expt 2 had clinical signs (Table 1). Whirling behavior was detected among TL rainbow trout at the 2 highest doses of exposure in Expt 1 , but in only 1 fish in the GR trout at the highest dose. Several fish of both strains of trout in Expt 1 at the highest dose of exposure had significant deformities, contracted secondary infections, and died before the $5 \mathrm{mo}$

Table 1. Oncorhynchus mykiss. Number of infected fish and number showing first onset of clinical signs (black tail, recorded at 5 mo post exposure) of whirling disease among strains TL (Trout Lodge) and GR (German) after exposure to graded doses of triactinomyxons of Myxobolus cerebralis $\left(\right.$ TAMs fish ${ }^{-1}$ ). Fish ages were ca. 570 and 999 degree-days in Expts 1 \& 2, respectively. 10 fish were examined in each case. Rep: replicate

\begin{tabular}{|c|c|c|c|c|}
\hline \multirow[t]{2}{*}{$\begin{array}{l}\text { Strain } \\
\text { Dose }\end{array}$} & \multicolumn{2}{|c|}{$\begin{array}{c}\text { Expt } 1 \\
\text { No. of fish infected } \\
\text { (no. with signs) }\end{array}$} & \multicolumn{2}{|c|}{$\begin{array}{c}\text { Expt } 2 \\
\text { No. of fish } \\
\text { infected }\end{array}$} \\
\hline & Rep 1 & Rep 2 & Rep 1 & Rep 2 \\
\hline \multicolumn{5}{|l|}{ TL } \\
\hline 0 & $0(0)$ & $0(0)$ & 0 & 0 \\
\hline 10 & $7(0)$ & $5(0)$ & 1 & 0 \\
\hline 100 & $2(0)$ & $0(0)$ & 6 & 6 \\
\hline 1000 & $10(4)$ & $10(2)$ & 10 & 10 \\
\hline 10000 & $10(10)$ & $10(10)$ & 10 & 10 \\
\hline \multicolumn{5}{|l|}{ GR } \\
\hline 0 & $0(0)$ & $0(0)$ & 0 & 0 \\
\hline 10 & $0(0)$ & $0(0)$ & 0 & 0 \\
\hline 100 & $1(0)$ & $0(0)$ & 0 & 0 \\
\hline 1000 & $4(0)$ & $3(0)$ & 3 & 9 \\
\hline 10000 & $10(7)$ & $6(2)^{*}$ & 9 & 10 \\
\hline \multicolumn{5}{|c|}{$\begin{array}{l}{ }^{*} \text { Only } 6 \text { fish remained in this replicate group at } 5 \text { mo anc } \\
\text { all were infected }\end{array}$} \\
\hline
\end{tabular}


sampling date. Two other pathogens were found during necropsy evaluations of these dead fish, Flavobacterium psychrophilum and Ichthyobodo necatrix. All groups of fish were treated for $10 \mathrm{~d}$ with fluorfenicol $\left(10 \mathrm{mg} \mathrm{kg}^{-1}\right.$ fish $\left.\mathrm{d}^{-1}\right), 5 \mathrm{~d}$ with nitrofurazone $(10 \mathrm{ppm}$, $1 \mathrm{~h}$, once daily) and 3 times with formalin (1:6000 for $1 \mathrm{~h}$ ) beginning at $1 \mathrm{~d}$ and then again at $42 \mathrm{~d}$ post exposure in Expt 1 and at $14 \mathrm{~d}$ post exposure in Expt 2. Losses due the bacterium and flagellate resulted in only 6 fish being collected from 1 of 2 replicate groups at the highest exposure dose of GR trout in Expt 1.

Black tail and whirling were first detected among TL rainbow trout in the highest exposure groups at $6 \mathrm{wk}$ post exposure and at $7 \mathrm{wk}$ in the 1000 TAMs dose. Black tail and 1 whirling fish were evident in GR trout at the highest exposure dose at $7 \mathrm{wk}$ post exposure. No quantitative assessments of the prevalence of several observed skeletal deformities, which included a shortened operculum, sunken cranium, bent tail and malformed jaws, were made due to the subjective nature of the evaluation criteria. These deformities however, were most prominent in TL fish exposed to the 2 highest doses and GR trout only at the highest exposure dose in Expt 1.

The prevalence of infection at 5 mo post exposure was greater at each exposure dose among groups of TL than among GR rainbow trout (Table 1). At the highest dose of exposure to Myxobolus cerebralis, all TL fish examined at 5 mo were infected in Expts 1 \& 2. At the same dose, 100 and $95 \%$ of the GR rainbow trout were infected in Expts 1 \& 2, respectively. Greater differences between the 2 trout strains in the prevalence of infection were observed at the lower doses. At a dose of $1000 \mathrm{TAMs}, 100 \%$ of the TL rainbow trout were infected in both Expts 1 \& 2. In contrast, at the 1000 dose, only 35 and $60 \%$ of the GR trout in Expts 1 \& 2 were infected, respectively. Only 1 GR trout was infected at doses below 1000 TAMs, and that was in Expt 1. Infected TL rainbow trout were detected at doses of 100 and 10 in both Expts 1 \& 2. In Expt 1, a greater prevalence of infection was detected at the 10 compared to the 100 dose of exposure (Table 1) with the TL trout. We are uncertain why this occurred, and laboratory records did not suggest that there had been an unapparent switch in the samples of the 2 groups.

Differences in risk ratios demonstrated that the overall susceptibility (prevalence of infection) between TL and GR rainbow trout was statistically significant in Expt 1 $(p=0.011)$ and borderline significant $(p=0.130)$ when results for both experiments were combined (BreslowDay $\chi^{2}$ test for homogeneity of effect across strata [SPSS 1999]). Therefore, we may infer that the observed risk ratios vary for each dose level. The dose-specific risk ratios showed that TL rainbow trout were considerably more prone to infection than the GR rainbow trout at the chal- lenge dose of $10 \mathrm{TAMs} \mathrm{fish}^{-1}(\mathrm{RR}=13.3 ; 95 \% \mathrm{CI}=1.8$ to 96.8 ), and this difference in risk between trout strains decreased as challenge dose increased.

\section{Microscopic pathology}

Myxobolus cerebralis-associated lesion scores were greater in the TL than in the GR strain at all exposure doses (Fig. 1). Indeed, GR trout exposed to the 2 lower doses (100 and $10 \mathrm{TAMs}^{\mathrm{fish}}{ }^{-1}$ ) had no microscopic lesions associated with M. cerebralis. Some TL fish had microscopic lesions (particularly in cranial and gill cartilage) at all exposure doses (Fig. 1). In general, the severity of lesions increased with increasing dose of exposure in both strains of trout, with the exception of

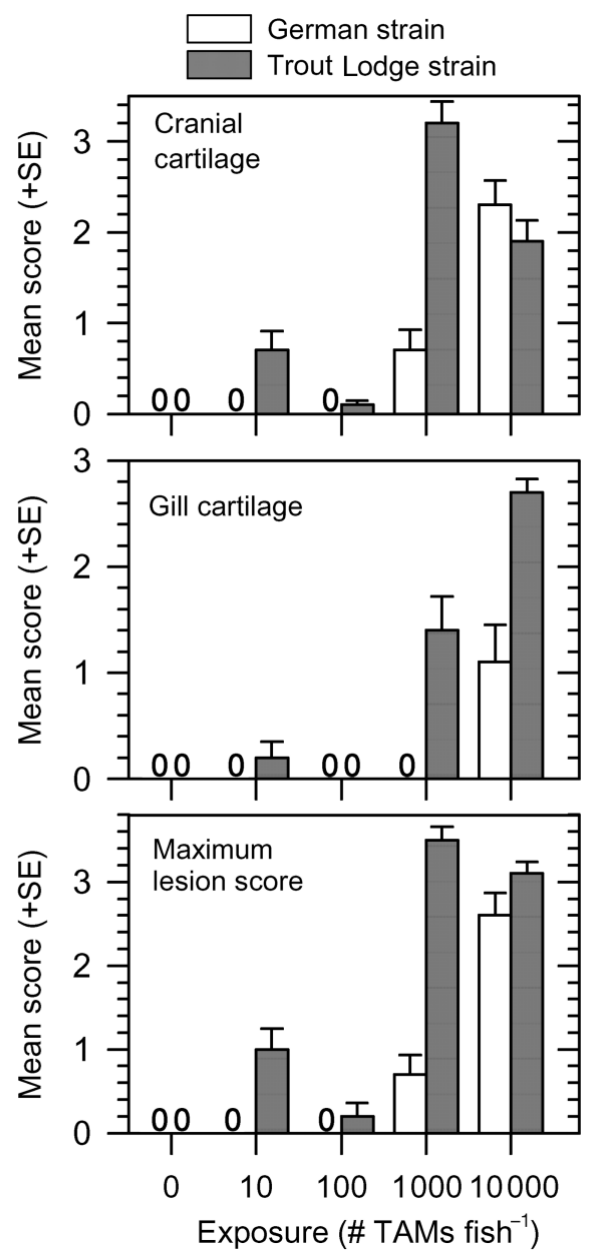

Fig. 1. Oncorhynchus mykiss. Severity of microscopic lesions in North American (TL) and German (GR) rainbow trout from Expt 1, 5 mo after exposure to graded doses of infectious stages of Myxobolus cerebralis. Lesions were scored as none (0), minimal (1), mild (2), moderate (3), or severe (4). Maximum lesion score for each fish was the greatest value from the 5 anatomical regions scored. TAMs: triactinomyxons 


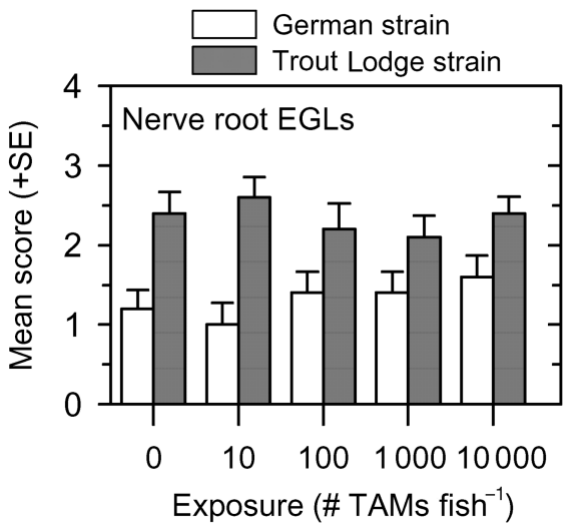

Fig. 2. Oncorhynchus mykiss. Mean scores for eosinophilic granular leukocytes (EGLs) in the cranial and spinal ganglia and nerve roots of TL and GR rainbow trout from Expt 1, 5 mo after exposure to graded doses of Myxobolus cerebralis triactinomyxons. Relative abundance of EGLs was scored as none (0), minimal (1), mild (2), moderate (3), or abundant (4). TAMs: triactinomyxons

the TL fish at doses of 10 and 100 TAMs in Expt 1 (Fig. 1). The mean lesion scores of the TL rainbow trout were 2 to 4 times greater than those of the GR strain at the 1000 TAMs dose, a dose at which lesions were detected in both groups of fish. There were few qualitative differences between the microscopic lesions observed in the 2 strains of trout, with the most severe lesions usually in the cranium and gill arches. Additional sites of infection included the vertebrae, fin rays, and ribs. The microscopic features of the parasite found in these tissues, including extrasporogonic and spore stages and accompanying cartilage degeneration and inflammation, were similar to previous descriptions (Halliday 1974, El-Matbouli et al. 1996, Baldwin et al. 2000). Eosinophilic granular leukocytes (EGLs) were common in cranial nerve ganglia and nerve roots of both rainbow trout strains, and mean scores were consistently greater in the TL strain (Fig. 2). However, scores for EGLs were not associated with exposure dose in either strain. Scored changes in hepatocellular glycogen had no clear patterns associated with fish strain or exposure dose.

\section{Spore concentrations in exposed fish}

Spores were detected among rainbow trout of both strains at the 2 highest doses of exposure in Expts 1 \& 2. At doses of 100 TAMs and lower, only 1 GR trout examined had spores and this was in Expt 1. In contrast, spores were found in TL fish at doses of 100 and 10 TAMs in both Expts 1 \& 2 (Table 2). The concentrations of spores ranged from none detected to $1.2 \times 10^{6}$ per half-head in TL rainbow trout and none to $4.0 \times 10^{5}$ in GR trout in Expt 1. The mean spore concentrations between strains of trout were different $(p \leq 0.001)$ at the 10 and 1000 exposure doses in Expt 1 (Table 2) and different $(p \leq 0.002)$ at doses of 100, 1000, and 10000 TAMs in Expt 2. The effect of age at exposure (Expt 1 vs Expt 2) was not significant when included in the linear model $(p=0.258)$, suggesting that this was not an important predictor of spore concentration at 5 mo post exposure. This non-significant experiment effect allowed the valid combination of data from both Expts 1 \& 2, which showed that mean spore counts were different between the strains of trout at all doses of exposure (Table 2).

\section{DISCUSSION}

Graded experimental exposure to triactinomyxon stages of Myxobolus cerebralis revealed striking differences in the susceptibility of 2 strains of rainbow trout to infection and subsequent development of gross and microscopic signs of whirling disease. The GR strain was clearly more resistant than TL rainbow trout with respect to the onset and severity of clinical signs,

Table 2. Oncorhynchus mykiss. Risk of infection analyses and mean spore counts of Trout Lodge (TL) and German (GR) strains of rainbow trout exposed to Myxobolus cerebralis in Expts 1 \& 2 (fish ages ca. 570 and 999 degree-days, respectively). 1 indicates an equal risk of infection, greater values show increased risk in TL compared to GR rainbow trout. TAMs: triactinomyxons; p: exact p-value based on 2-sided Mann-Whitney non-parametric comparison of mean ranks; nd: not determined, because of complete agreement between strains

\begin{tabular}{|c|c|c|c|c|}
\hline \multirow{2}{*}{$\begin{array}{l}\text { Challenge } \\
\text { dose } \\
\text { (TAMs fish }^{-}\end{array}$} & \multirow{2}{*}{$\begin{array}{r}\text { Risk ratio } \\
(95 \% \text { CI) }\end{array}$} & \multicolumn{3}{|c|}{ - Mean spore count } \\
\hline & & $\mathrm{TL}$ & GR & $\mathrm{p}$ \\
\hline \multicolumn{5}{|l|}{ Expt 1} \\
\hline 0 & nd & 0.0 & 0.0 & nd \\
\hline 10 & $12.4(1.8,86.7)$ & 15312.5 & 0.0 & 0.001 \\
\hline 100 & $2.0(0.2,20.3)$ & 1750.0 & 187.5 & 0.799 \\
\hline 1000 & $2.7(1.5,4.9)$ & 400855.3 & 3881.6 & $<0.001$ \\
\hline 10000 & nd & 232312.5 & 250312.5 & 0.582 \\
\hline \multicolumn{5}{|l|}{ Expt 2} \\
\hline 0 & nd & 0.0 & 0.0 & nd \\
\hline 10 & $1.9(0.2,19.5)$ & 750.0 & 0.0 & 0.792 \\
\hline 100 & $11.4(1.6,79.4)$ & 12437.5 & 131.6 & 0.002 \\
\hline 1000 & $2.9(1.6,5.2)$ & 220250.0 & 2687.5 & $<0.001$ \\
\hline 10000 & $1.1(1.0,1.2)$ & 343947.4 & 39562.5 & $<0.001$ \\
\hline \multicolumn{5}{|c|}{ Combined } \\
\hline 0 & nd & 0.0 & 0.0 & nd \\
\hline 10 & $13.3(1.8,96.8)$ & 8031.3 & 0.0 & $<0.001$ \\
\hline 100 & $6.8(1.7,28.1)$ & 7093.8 & 160.3 & 0.001 \\
\hline 1000 & $2.8(1.8,4.2)$ & 308237.2 & 3269.2 & $<0.001$ \\
\hline 10000 & $1.0(1.0,1.1)$ & 286698.7 & 133229.2 & $<0.001$ \\
\hline
\end{tabular}


risk and severity of infections, and production of spores. The differences in the responses of these 2 trout strains to experimental infections with $M$. cerebralis in laboratory trials, combined with empirical evidence collected from the field, provide the most convincing evidence to date that some rainbow trout are more resistant to whirling disease.

Studies to date have failed to identify strains of rainbow trout present in North America that demonstrate significant resistance to whirling disease (O'Grodnick 1979, Markiw 1992a, Hedrick et al. 1998, 1999a,b, 2001, Thompson et al. 1999, Densmore et al. 2001, MacConnell \& Vincent 2002). This may be due in part to a shorter period of co-evolution of the host and parasite. The parasite was presumed to have been introduced to the east and west coasts of the USA in the early 1950s and mid-1960s, respectively, with frozen rainbow trout from Europe (Hoffman 1970, 1990, Modin 1998). Therefore rainbow trout in the USA have had only $50 \mathrm{yr}$ of effective contact with the parasite. In contrast, at sites in Europe (including Germany) up to $110 \mathrm{yr}$ of co-evolution between the parasite and rainbow trout has occurred. Rainbow trout surviving under these hatchery conditions have subsequently been used for brood stocks (Schäperclaus 1986). We have considered that differences in the virulence of the parasite, as found in Europe and the USA, may explain the absence of whirling disease outbreaks in recent years among rainbow trout stocks from Germany. Initial studies of conserved and variable regions of the ribosomal genes of a limited number of Myxobolus cerebralis isolates from North American and Germany however, have not shown appreciable differences (Andree et al. 1999). Furthermore, the recent practice in Germany of reintroducing eggs of rainbow trout from North America to local trout farms, has demonstrated that these fish contract $M$. cerebralis infections and severe whirling disease (El-Matbouli unpubl. obs.). Together, these studies and observations suggest that changes in the host resistance, not parasite virulence, are the principal factors responsible for the lack of whirling disease among rainbow trout from certain German brood stocks.

Our experimental trials with the GR strain of rainbow trout clearly show its greater resistance to infection and subsequent disease. In Expt 1, conducted with younger age-matched groups of each trout strain, both infections and disease, as determined by gross signs and microscopic lesions, were pronounced in the TL compared to the GR rainbow trout. However, resistance can be overwhelmed by high doses of parasite exposure, as shown in the current study at the 10000 TAMs dose in Expt 1, and as previously shown with brown trout at the same dose (Hedrick et al. 1999a). The effects of increasing age and greater resistance to the gross clinical signs of whirling disease were evident in comparisons of Expts 1 \& 2. The same doses of triactinomyxons that induced whirling and black tail in Expt 1 failed to induce any clinical signs in either trout strain in Expt 2. Despite the absence of clinical signs, an increased prevalence of infection and greater mean spore concentrations, as found in Expt 1, were again evident in TL compared to GR rainbow in Expt 2. These results demonstrate that the age-related resistance known for susceptible strains of rainbow trout in North American trials (Hoffman \& Byrne 1974, Markiw 1991) also occurs with the GR trout strain.

The mechanisms underlying the greater resistance of the GR strain compared to more susceptible strains of rainbow trout are currently unknown. Our microscopic pathological comparisons did not demonstrate readily detectable qualitative differences in the lesions found in infected trout of either strain. This contrasts with studies comparing brown trout to rainbow trout following natural or experimental exposure to Myxobolus cerebralis that have demonstrated both quantitative and qualitative differences in the response to infection (Hedrick et al. 1999a, Baldwin et al. 2000). Baldwin et al. (2000) found that juvenile brown trout exposed in live cages in an enzootic stream in Montana, USA and examined 3 mo later had a lower prevalence of infection (5\%) and much milder lesions ( 0.06 on a scale of 0 to 4 ) than exposed age-matched rainbow trout (prevalence $85 \%$, lesion severity 3.28 ). Similar results were obtained in comparisons of brown and rainbow trout in experimental exposures to graded doses of triactinomyxons in laboratory trials (Hedrick et al. 1999a). In both field and laboratory trials, the principal lesions in rainbow trout were in cranial (ventral calvarium) and gill arch cartilage; lesions were also found in vertebrae, jaws, opercula, and fin rays. In contrast, cranial and vertebral infections were rare and the most severe lesions were found in the gill arches of brown trout. These differences in the tissue sites and severity of infection explain why rainbow trout experience increased clinical signs of black tail and whirling (Rose et al. 2000) compared to brown trout. Increased numbers of eosinophilic granular leucocytes (EGLs) in root nerve ganglia have been found in brown trout and coho salmon, both fish species with resistance to $M$. cerebralis (Hedrick et al. 1999a, 2001). These EGLs are mast-like cells found in teleostean fishes principally in mucosal tissues of the gut and nares (Holland \& Rowley 1998, Reite 1998). Although their numbers can increase during chronic parasitic infections, their function in the immune response is unknown. There was no indication that EGLs increased in the GR trout following infection as found with more resistant brown trout and coho salmon. We presume that the GR trout limit the number of parasites that reach the cartilage, 
thus minimizing cartilage lysis and the numbers of spores formed later in development. We are examining the expression of cytokines that may increase the efficiency of the host cellular responses involved in parasite elimination in the GR trout as 1 potential mechanism that is known to influence the resistance to diseases in other animals (Hawken et al. 1998).

Spore concentrations in infected TL fish reached $1.2 \times 10^{6}$ per half-head at the 1000 TAMs exposure dose in Expt 1. This concentration is equivalent to the highest reported spore concentrations detected in both experimentally and naturally infected rainbow trout (Markiw 1992b, Hoffman \& Byrne 1974, Markiw \& Wolf 1974b, O'Grodnick 1979). This spore concentration must represent an upper limit, as exposure of rainbow trout to even higher doses of triactinomyxons both in our study and that of Markiw (1992b) failed to approach or exceed this value (Table 2). This upper threshold in TL fish occurred at the 1000 TAMs dose in Expt 1 and at the 10000 TAMs dose in Expt 2 (Table 2). Differences between the upper threshold in Expts 1 \& 2 are presumed to reflect the increased resistance with age, thereby requiring greater doses of exposure to obtain similar spore production in infected fish. In contrast to the TL fish, spore concentrations in the GR trout showed a dose-dependent response, with the upper limit only obtained at the 10000 TAMs dose (Table 2). The greatest spore concentration of $4.5 \times 10^{5}$ per halfhead was found in a GR trout exposed to the 10000 TAMs dose in Expt 1. Overall, the numbers of spores in infected GR trout were significantly less, sometimes over 100 -fold less the number of spores in TL fish at the same exposure dose (Table 2).

Reduced spore production following infection of GR trout with Myxobolus cerebralis has important implications for the perpetuation of the parasite in both captive and wild fish populations. If fewer fish in the population become infected and those fish produce reduced numbers of spores, there should be reduced opportunities for infections in the oligochaete host. Depending on the aquatic system, this might significantly influence overall parasite burdens in the environment pushing the equilibrium in favor of the host rather than the pathogen. How stocking more resistant trout in more-complex aquatic ecosystems might influence the parasite burden and subsequent impacts of whirling disease on wild trout is unknown, although experiments stocking older and more-resistant rainbow trout have been conducted in several states in the USA. It is important to understand that resistance to a single disease is only 1 of many critical criteria that need to be considered when moving plants and animals from one geographic region to another (Hawken et al. 1998). The broader ecological implications of movements of plants and animals should be consid- ered. If not, greater harm than good may result, a lesson learned years ago with the introduction of nonnative salmonids throughout the USA (Allendorf et al. 2001).

The experiments reported in this study clearly show that the GR strain of rainbow trout has acquired an increased resistance to whirling disease compared to strains from North America. This resistance was demonstrated under laboratory conditions, in which doses of exposure and subsequent environmental parameters were controlled. The mechanisms that underlie the observed resistance are currently being studied with the aim of providing useful data for potential fisheries management of rainbow trout in waters where whirling disease is endemic. A second phase of our studies with the GR trout will be to explore their resistance to experimental infections with commonly occurring pathogens found in North America that might differ from those found in Europe. In addition, these trout will be thoroughly examined to determine if pathogens unknown in North American trout are potentially transmitted with them via eggs. It is our view that such studies are critical before further discussions on the potential applications of these fish in North America can proceed.

Acknowledgements. This work was supported in part by the Whirling Disease Foundation, the US Fish and Wildlife Service and the California Department of Fish and Game. We thank Dr. William Cox, Senior Pathologist, California Department of Fish and Game, for his assistance in various parts of the study.

\section{LITERATURE CITED}

Allendorf FW, Spruell P, Utter FM (2001) Whirling disease and wild trout: Darwinian fisheries management. Fisheries (Bethesda) 26(5):27-29

Andree KB, El-Matbouli M, Hoffmann RW, Hedrick RP (1999) Comparison of 18S and ITS-1 rDNA sequences of selected geographic isolates of Myxobolus cerebralis. Int J Parasitol 29:771-775

Baldwin TJ, Vincent ER, Siflow RM, Stanek D (2000) Myxobolus cerebralis infection in rainbow trout (Oncorhynchus mykiss) and brown trout (Salmo trutta) exposed under natural stream conditions. J Vet Diag Inv 12:312-321

Bartholomew JL, Wilson CJ (2002) Whirling disease: reviews and current topics. Am Fish Soc Symp 29:43-143

Densmore CL, Blazer VS, Cartwright DD, Schill WB, and 6 others (2001) A comparison of susceptibility to Myxobolus cerebralis among strains of rainbow trout and steelhead in field and laboratory trials. J Aquat Anim Health 220-227

El-Matbouli M, Fischer-Scherl T, Hoffman RW (1992) Present knowledge of the life cycle, taxonomy, pathology, and therapy of some Myxosporea spp. important for freshwater fish. Annu Rev Fish Dis 3:367-402

El-Matbouli M, Hoffmann RW, Mandok C (1996) Light and electron microscopic observations on the route of the triactinomyxon-sporoplasm of Myxobolus cerebralis from 
epidermis into rainbow trout (Oncorhynchus mykiss) cartilage. J Fish Biol 46:919-935

El-Matbouli M, Hoffmann RW, Shoel H, McDowell TS, Hedrick RP (1999) Whirling disease: Host specificity and interaction between the actinosporean stage of Myxobolus cerebralis and rainbow trout (Oncorhynchus mykiss) cartilage. Dis Aquat Org 35:1-12

Halliday MM (1974) Studies on Myxosoma cerebralis; a parasite of salmonids. II. The development and pathology of Myxosoma cerebralis in experimentally infected rainbow trout (Salmo gairdneri) fry reared at different water temperatures. Nord Vetmed 25:349-358

Halliday MM (1976) The biology of Myxosoma cerebralis; the causative agent of whirling disease of salmonids. J Fish Biol 9:339-357

Hawken RJ, Beattie CW, Schook LB (1998) Resolving the genetics of resistance to infectious diseases. Sci Tech Rev Int Off Epizoot 17(1)17-25

Hedrick RP (1998) Relationships of the host, pathogen and environment: implications for diseases of cultured and wild fish populations. J Aquat Anim Health 10:107-111

Hedrick RP, El-Matbouli M, Adkison MA, MacConnell E (1998) Whirling disease: re-emergence among wild trout. Immunol Rev 166:365-376

Hedrick RP, McDowell TS, Gay M, Marty GD, Georgiadis MP, MacConnell E (1999a) Comparative susceptibility of rainbow trout Oncorhynchus mykiss and brown trout Salmo trutta to Myxobolus cerebralis, the cause of salmonid whirling disease. Dis Aquat Org 37:173-183

Hedrick RP, McDowell TS, Mukkatira K, Georgiadis MP, MacConnell E (1999b) Susceptibility of selected inland salmonids to experimentally induced infections with Myxobolus cerebralis, the causative agent of whirling disease. J Aquat Anim Health 11:330-339

Hedrick RP, McDowell TS, Mukkatira K, Georgiadis MP (2001) Susceptibility of three species of anadromous salmonids to experimentally induced infections with Myxobolus cerebralis, the causative agent of whirling disease. J Aquat Anim Health 13:43-50

Hofer B (1903) Ueber die Drehkrankheit der Regenbogenforelle. Allg FischZtg 28:7-8

Hoffman GL (1970) Intercontinental and transcontinental dissemination and transfaunation of fish parasites with emphasis on whirling disease (Myxosoma cerebralis). In: Snieszko SF, (ed) Disease of fish and shellfish, American Fisheries Society, Washington, DC, p 69-81

Hoffman GL (1990) Myxobolus cerebralis, a worldwide cause of salmonid whirling disease. J Aquat Anim Health 2: 30-37

Hoffmann GL, Byrne CJ (1974) Fish age as related to susceptibility to Myxosoma cerebralis, cause of whirling disease. Prog Fish-Cult 36:151

Hoffman GL, Putz RE (1969) Host susceptibility and the effect of ageing, freezing, heat, and chemicals on the spores of Myxosoma cerebralis. Prog Fish-Cult 31:35-37

Editorial responsibility: Wolfgang Körting,

Hannover, Germany
Holland JW, Rowley AF (1998) Studies on the eosinophilic granule cells in the gills of the rainbow trout, Oncorhynchus mykiss. Comp Biochem Physiol 120:321-328

MacConnell E, Vincent ER (2002) The effects of Myxobolus cerebralis on the salmonid host. In: Bartholomew J, Wilson $\mathrm{C}$ (eds) Whirling disease: review and current topics. Am Fish Soc Symp No. 29, American Fisheries Society, MD, p 95-108

Markiw ME (1991) Whirling disease: earliest susceptible age of rainbow trout to the triactinomyxid of Myxobolus cerebralis. Aquaculture 92:1-6

Markiw ME (1992a) Salmonid whirling disease. US Fish Wildl Serv Fish Wildl Leafl 17:1-11

Markiw ME (1992b) Experimentally-induced whirling disease. I. Dose response of fry and adults of rainbow trout exposed to the triactinomyxon stage of Myxobolus cerebralis. J Aquat Anim Health 4:40-43

Markiw ME, Wolf K (1974a) Myxosoma cerebralis: isolation and concentration from fish skeletal elements - sequential enzymatic digestions and purification by differential centrifugation. J Fish Res Board Can 31:15-20

Markiw ME, Wolf K (1974b) Myxosoma cerebralis: comparative sensitivity of spore detection methods. J Fish Res Board Can 31:1597-1600

Modin J (1998) Whirling disease in California: a review of its history, distribution, and impacts, 1965-1997. J Aquat Anim Health 10:132-142

Nehring RB, Walker PG (1996) Whirling disease in the wild: the new reality in the intermountain west. Fisheries (Bethesda) 21:28-32

O'Grodnick JJ (1979) Susceptibility of various salmonids to whirling disease (Myxosoma cerebralis). Trans Am Fish Soc 108:187-190

Reite OB (1998) Mast cells/eosinophilic granule cells of teleostean fish: a review focusing on staining properties and functional responses. Fish Shellfish Immunol 8:489-513

Rose JD, Marrs GS, Lewis C, Schisler G (2000) Whirling disease behavior and its relation to pathology of the brain stem and spinal cord in rainbow trout. J Aquat Anim Health 12:107-118

Schäperclaus W (1931) Die Dreh-Krankheit in der Forellenzucht und ihre Bekämpfung. Z Fish Hilfswiss 29:521-567

Schäperclaus W (1986) Fish diseases. Vol. 2, Akademie-Verlag, Berlin, p 665-666

Thompson KG, Nehring RB, Bowden DC, Wygant T (1999) Field exposure of seven species or subspecies of salmonids to Myxobolus cerebralis in the Colorado River, middle fork, Colorado. J Aquat Anim Health 11:312-329

Vincent ER (1996) Whirling disease and wild trout: the Montana experience. Fisheries (Bethesda) 21:32-34

Wolf K, Markiw ME (1984) Biology contravenes taxonomy in the Myxozoa: new discoveries show alternation of invertebrate and vertebrate hosts. Science 225:1449-1452

Yoder WG (1972) The spread of Myxosoma cerebralis into native trout populations in Michigan. Prog Fish-Cult 34: 103-106

Submitted: August 8, 2002; Accepted: January 14, 2003

Proofs received from author(s): June 11, 2003 